\title{
Case Study of Results of Autistic Children Images in Middle School
}

\author{
Andi Suryadi* \\ Department of Fine Arts Education \\ Universitas Pendidikan Indonesia \\ Bandung, Indonesia \\ *andisuryadi@upi.edu
}

\author{
Ramadita Fetrianggi \\ Visual Communication Design Study Program \\ Universitas Pendidikan Indonesia \\ Bandung, Indonesia \\ ramaditafetrianggi@upi.edu
}

\begin{abstract}
Autism is a developmental disorder that affects child motoric sensors and cause children to have a disruption in their social life. Children with special needs (ABK) especially for children with autism, their creativity can be developed through drawings, paintings, music, dance and others. Picture is a language, children with autism can communicate with pictures, they do it naturally compared to writing that they do not understand. Lack of creativity or can be called the deficit of imagination is a common stereotype in children with autism. Some deficiencies in this autistic child make it difficult for them to express their imagination. Yet today, children's drawing are a manifestation of their growth, about how to express their imagination and how much environmental influence their perception of a thing. According to Victor Lowenfeld, childrenes drawing can be classified according to age bracket. This study examines a number of things related to pictures of autistic children in Temara Ilmu Junior High School of Bandung. The formulation of the problem among others, (1) How is the process of drawing of autism children in in Temara Ilmu Junior High School of Bandung? (2) How are the drawing of autism children (visual elements) in in Temara Ilmu Junior High School of Bandung? The purpose of this study is to analyze the process and the results of drawing of children with autism in in Temara Ilmu Junior High School of Bandung. The results of the research have shown that if the exclusion of techniques should be used, children with autism are good visual learners, but lack of motoric skills and their deficit of imagination prevent them. Apparently they only imitate the object of the given image without adding another object according to the instruction. Their process of drawing is also much assisted by other parties. If their (an autistic child ${ }^{\mathrm{ee}} \mathrm{s}$ ) drawing was compared with Lowenfeld theory, there is only one child that can be quite the same. The results of the images of the three children when linked to the normal child picture period are one stage below the normal child. Images can be used by children with autism to communicate, helping skills in language and vocabulary.
\end{abstract}

Keywords-Wimba, pictures of the child, an autistic child, visual static, visually dynamic

\section{INTRODUCTION}

Autism in medical and psychological terms is a pervasive developmental disorder characterized by a distortion in the development of multiple basic psychological functions, such as the development of behavior, language, and motor movements. It is not surprising that people with autism experience disorders in carrying out cognitive, emotional, and psychomotor functions [1].

One of the problems in children with autism is communication problems. Communication is a two-way process that involves someone giving the message and another person receiving it and acting according to the message. According to Bondy and Frost [2] the purpose of communication is to express desires, express feelings, and exchange information.

There are two important components in creating effective communication, the first component is the ability to understand messages (understanding), namely the ability to listen to sounds or see actions, the ability to process messages, and memory storage. The second component is the ability to respond to messages (expressions), namely the ability to choose the right words or actions, the ability to compose words and actions into understandable messages [3].

In children with autism, it was found that not all of them could speak verbally, some even spoke non-verbally until adults. communication limitations in children with autism include; autistic children with verbal communication, where children can talk but not necessarily be able to communicate. Communication is not optimal, where the child only repeats the words or originates speaking when asked, the answers given are not connected or not in accordance with the question.

In learning children with autism cannot be separated from the use of media, especially visual media, because visual media (pictures) are a communication tool that realizes the communication goals of children, and in addition, children learn to understand more easily through pictures (visuallearners). Gemah said that many children with autism get better results when learning by using visuals (vision) [4]. Visual learning makes it easier for children with autism to be able to concentrate and understand something, for example by looking at concrete objects, color photos, pictures or symbols. Education through visual media is a method / way to get a better understanding of something that can be seen than 
something that is heard or read. Using visual media can increase the effectiveness and efficiency of the learning process, especially in learning children with autism.

Children with autism have a unique characteristic in learning, namely easy to understand and remember various things that are touched (visual learner or visual thinking), easy to understand the things they experience (hands on learner), therefore users of tools use visual strategies (visual aids)) a variety of can be used in teaching communication skills. Visual media often used by therapists include flash cards, COMPIC, and PECS. For children with special needs (ABK), especially for children with autism, creativity is channeled through pictures, paintings, music, dance and so on. Being creative is a self-determination, which is a choice for someone to act creatively or not $[5,6]$.

Autism is a disorder that affects several aspects of a child's life. Social development and communication, are the most important disorders, like normal individuals, abnormalities in verbal intelligence or language and difficulties in actualizing behavior, persistently, desire, pleasure and routine. Children with autism have characteristics, namely; (1) disturbances in the field of verbal and non-verbal communication; (2) disturbance in the field of social interaction (3) disturbance in the field of behavior and play (4) disturbance in the field of feelings and emotions and; (5) disturbances in sensory perception [7].

Basically, in doing art, children involve creativity, so that all emotions and thoughts that settle will be "externalized" or channeled in the form of points, lines, fields, shapes, spaces, colors, and intensity in the form of symbols. The symbols formed in these works are sometimes formed, consciously or unconsciously, so that they have a meaning that is directly related to the child's imagination and there is also a child's root problem [8].

Children with autism capture more visual language than word language. For this reason, the author intends to examine children with autism from the drawing process they make [9]. By drawing, children with autism can help with emotional development, so that children can understand what makes them feel happy, sad, or afraid. Children with autism are gifted with excellent visual memory and have the ability to think in pictures. Children with autism have a better memory of written pictures and texts than direct spoken dialogue. This fact makes children with autism unique in the image [10]

\section{Methods}

To make it easier to analyze a study of the object under study, theory and related references are needed. The theory used in this research is visual language theory, and as a reference, creativity theory is used. The theory used is the predecessor theory of visual language with a drawing system called Primadi Tabrani's 'Flat Space-Time'. Visual language is a new 'science', born in Indonesia around 1980 and culminating in the dissertation of Primadi Tabrani which is a comparative study of prehistoric-primitive-traditional-children's visual language and modern visual language [11]. With this knowledge, we can now read prehistoric, primitive, traditional, and children's cave drawings, even though the pictures are practically "full" pictures without text.

To be able to understand what children draw as a form of expression and pour out their hearts, understanding is needed so they can understand what children want to convey through the child's visual language. Visual language is very important in understanding children's drawings.

The approach used in this study is a qualitative approach, which is basically an approach used to reveal the lives of people in their environment, through interaction with them, understanding language, interpretation or perception as well as imagination and creativity [12]. Research in the social sciences has so far recognized two paradigms in approaching problems. This paradigm helps researchers understand about social phenomena, how science can be formed, and what affects the problem, its solution, and the criteria for the scientific evidence found. The first paradigm is positivism and the second is phenomenological [13]. In the first paradigm, an understanding of social problems is based on theoretical testing which is composed of quantitative, measurement involving numbers, and is analyzed using statistical procedures. This paradigm is consistent with the so-called quantitative approach, with the aim of predicting the generalizability of a theory. Qualitative research is the process of searching for data to understand social problems which is based onresearch holistic, formed by words, and derived from natural situations [12].

In qualitative research, researchers try to understand the subject from their own frame of mind. Thus, what is important is the experience, opinions, feelings and knowledge of the participants. Therefore, all perspectives are of value to researchers. The researcher doesn't see right or wrong, but all important data. This approach is often referred to as a humanistic approach, because researchers do not lose the human side of a social life. Researchers are no longer limited by numbers, statistical calculations, variables that reduce the value of individual uniqueness.

\section{RESUltS AND DISCUSSION}

Children are given the freedom to make their own decisions, free to choose and do it in their own way. They are free to create through art, the teacher accepts what the children will do by reaffirming and mobilizing them to be able to express according to their respective perspectives. Unique forms of expression for children will be appreciated in the process of making them and here the teacher gives a feeling of confidence to learn and develop their behavior and life skills.

The object that the child depicts is Wimba which has a different way of depiction and expression in each image. As expressed by Primadi Tabrani in his theory of language, [4] (2012: 185), namely the way of depiction seen from the size of the take, the angle of taking, the scale, the depiction, and the way it is seen. How to arrange Wimba in one image area or between image fields so that it tells a story [6], Primadi [14], is 
an expression system, there are two types of expression, namely the inner and outer ones. In this study, the expression used to determine the static visual elements in children's images is to use inner speech, namely how to use it in compiling images in one image area, so that it tells stories that states space, states motion, states time and space, and states importance. Meanwhile, to find out the dynamic visual elements, when children with autism respond to objects by being treated through movement or movement (kinetic), or visual elements that are produced from graphic effects while drawing, the child imitates Wimba's voice, makes movement patterns or events. about the wimba.

Dynamic visuals in the work of children with autism can be seen in the creative process of children. The theory of creativity with a four approach. P. Rhodes calls the four definitions of creativity as the Four P's of Creativity: Person, Press, Process, and Product. Person (Personal), the unique personality of each child with autism can lead to creativity so that they can come up with innovative ideas or products. Press (Pusher), creativity can arise because of internal motivation (coming from oneself) and external motivation (coming from the environment). Process, in this case children should be given the freedom and opportunity to work so that they can process and be able to produce creative products. Product (Product), related to personal, driving and process, creative children can produce creative products as well.

The wimba shape depicted is a symbol that can be read to recognize and understand the personality of a child, either through the lines they paint, the colors they choose, or the wimba they place on a picture plane. The cognitive domain of knowledge of children with autism and the affective domain of the behavior of children with autism is expressed in the realm of psychomotor. What the child knows and what the child feels is applied in a picture. Creativity that is created with channeled emotions is processed into one in the form of a work that can be interpreted using visual language theory to express the art.

\section{CONCLUSIONS AND RECOMMENDATIONS}

The communication process they experience is stored in memory which will be appreciated according to the emotions they feel when drawing. The drawing activity is a medium for playing, communicating, expressing feelings, and expressing ideas, ideas, and imagination. The object that is described by autistic junior high school children in terms of knowledge is a static visual element, namely the wimba which has a different way of depicting and expressing itself in each image. Both the size of the take, the angle of taking, the scale, and the way of the depiction conveyed through an image that states space, motion, time and space, also states importance.

The creative process that is created with channeled emotions is processed into one in the form of a work in which the autistic child interacts, moves, or mimics when drawing so it is called dynamic visual elements. These two elements are interpreted by means of visual language theory to express the art, creativity theory to express the creative process and emotions.

The meaning of the wimba depicted is a symbol that can be read to identify and understand the personality of a child, both through the lines they paint, the colors they choose, and the wimba they place on a plane of paper. The cognitive domain of children's knowledge and the affective domain of children's behavior is expressed in the realm of psychomotor. What the child knows and what the child feels is applied in a picture.

\section{A. Drawing of "Floating Market" in Nazario's work}

Figure 1 show Media colorand a brush paperon A3size white HVS paper by Nazario Prianggara Kurnia (Dena) Drawing of "Floating Market".

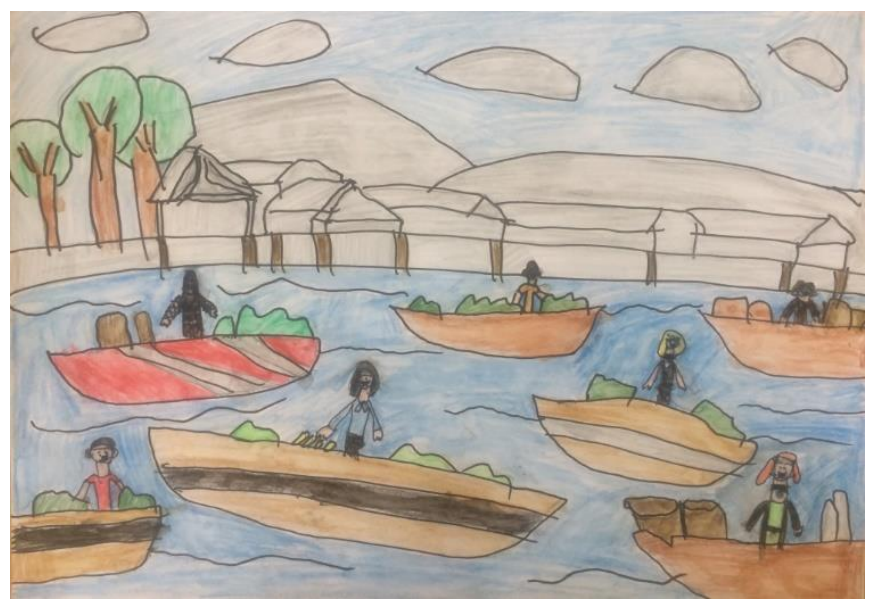

Fig. 1. by Nazario Prianggara Kurnia (Dena) "Drawing of a Floating Market" Media colorand a brush paperon A3size white HVS paper

1) Person: Before learning, Nazario always routinely started his first activities with something he liked, namely opening his laptop and then opening thefile videothat had been downloaded earlier at home. At that time, Nazario's laptop experienced a problem, namely it was difficult to open the application because the computer storage system was full of downloaded game and video applications. Due to his initial routine of having to open the laptop, the teacher finally lent him the laptop for Nazario to use. If a laptop is not given and it starts immediately with drawing activities, it is feared that the child will scream and get angry by hitting himself because he feels disappointed, there is something that has not been realized.

2) Press: When Nazario was using the teaching laptop, there was a video file of one of the old television commercials, RCTI, with a floating market scene. Nazario had repeated the video several times, at this time the instructor immediately submitted a communication that the video was set in the atmosphere of a floating market located in South Kalimantan. Not long after, Nazario opened a search application and searched for information in the form of images about the 
floating market. After this process, the teacher began to communicate more deeply by asking what picture he saw. It is intended that the child restates what he experienced or observed. The atmosphere of the floating market show in figure 2 .

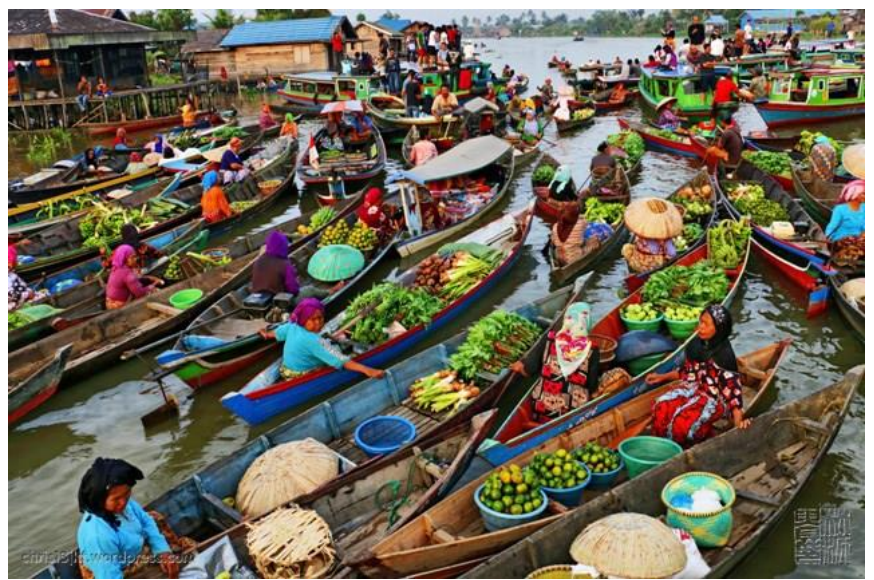

Fig. 2. The atmosphere of the floating market on the Baritoriver [15].

3) Process: After doing the above activities, then the children are invited to appreciate the atmosphere of the floating market through pictures. Nazario was released to create the atmosphere of a custom floating market that he liked and the teachers did not impose the will of the children. Nazario can describe the atmosphere with what the child wants and realize his ideas according to the imagination that Nazario got during the beginning of the lesson. When the drawing process took place, Nazario started talking over and over again by mentioning the word Barito, which means that the picture of the atmosphere is in the location of the Barito River, South Kalimantan. Teachers are reminded not to be expressed or discussed continuously, this is to reduce the habit of children to repeat the same words and are directed to be able to say them into simple sentences. Not only saying words, Nazario also moved his left hand like twisting it in a horizontal position, the author interpreted that he was describing a moving river. Nazario also moves his body up and down in a sitting position, this means that Nazario is on a floating ship.

4) Product: In the sample image that has been selected above you can see that. Nazario's abilities are created through physical, creative and rational work, which is when his feelings merge not only with movement but also with his imagination. Nazario really felt and responded to what he got during this lesson. It starts when the teacher tells about the state of the floating market, sees a video about the floating market. It can be concluded that with a series of these activities, which involve rational, physical and creative abilities Nazario can express what he has seen, heard, done, and felt both in the left brain and right brain responses that he lived in intuition both in a conscious state, the threshold of conscious, or unconsciousness, that Nazario has revealed in a picture.

\section{REFERENCES}

[1] M. Abdurahman, Pendidikan Bagi Anak Berkesulitan Belajar. Jakarta : Rineka Cipta, 2010

[2] S. Fadhilah and S. Sjah, Membantu Anak ASD (Autisme Spectrum Disorder) Berkomunikasi Secara Efektif. Koferesi Nasional Autisme Jakarta: Perhimpunan Dokter Specialis Kedokteran Jiwa Indonesia, Ikatan Dokter Anak Indonesia, Perhimpunan Dokter Specialis Saraf Indonesia, 2013.

[3] B. Dredge and Croswhite, Communication Without Speech- A Guide to Parent and Proffesionals. Australia: Victoria, Commonwealth School Commission.

[4] N. Gemah, Alat Bantu Visual. Bandung: Jatis Hurip, 2014.

[5] R. Davido, Mengenal Anak Melalui Gambar. Jakarta : Salemba Humanika, 2012.

[6] A. Arsyad, Media Pembelajaran. Jakarta : PT. Raja Grapindo Persada, 2016.

[7] D.S. Prasetyono, Serba-serbi Anak Autis. Jogjakarta: DIVA Press, 2011.

[8] P. Christie, E. Newson, W. Prevezer and S. Chandler, Langkah Awal Berinteraksi dengan Anak Autis. Jakarta : PT Gramedia Pustaka Utama \& Kompas Gramedia, 2010.

[9] A. Liliweri, Komunikasi Verbal dan Nonverbal. Bandung : PT Citra Aditya Bakti, 2010.

[10] P. Tabrani, Proses Kreasi - Gambar Anak - Proses Belajar. Bandung : Erlangga, 2013.

[11] P. Tabrani, Bahasa Rupa. Bandung: Kelir, 2012.

[12] J.L. Moleong, Metodologi Penelitian Kualitatif. Bandung: PT. Remaja Rosdakarya, 2010.

[13] Bogdan and Taylor, Pengantar Metode Penelitian Kualitatif; Suatu Pendekatan Fenomenologis Terhadap Ilmu-Ilmu Sosial. Ditermahkan oleh Arief Furchan. Surabaya: Usaha Nasional, 2012.

[14] A. Primadi, B.S. Kim and K.B. Lee, "Tarsal tunnel syndrome after total ankle replacement - a report of 3 cases," Acta orthopaedica, vol. 87, no. 2, pp. 205, 2016.

[15] Rakyat Merdeka, [online] retrieved from: https://i1.wp.com/www.rakyatmerdeka.co/wpcontent/uploads/2016/06/img_lbm09-1.jpg? Fit $=640 \% 2 \mathrm{C} 426$ 